\title{
Use of fiberglass CAD-CAM post-and-core for rapid orthodontic extrusion of anterior tooth - Case Report
}

Uso de pino de fibra de vidro CAD-CAM para extrusão ortodôntica rápida de dente anterior Relato de Caso

Uso de postes y muñones CAD-CAM de fibra de vidrio para la extrusión ortodóncica rápida de diente anterior - Relato de Caso

Received: 11/21/2021 | Reviewed: 11/29/2021 | Accept: 12/02/2021| Published: 12/13/2021

Anderson Petrauskas
ORCID: https://orcid.org/0000-0001-8392-3094
Pontifícia Universidade Católica do Paraná, Brasil
E-mail: andersonpetrauskas@ hotmail.com
Bruna Luiza do Nascimento
ORCID: https://orcid.org/0000-0002-9511-8946
Pontifícia Universidade Católica do Paraná, Brasil
E-mail: drabrunadonascimento@ gmail.com
Isabelle Adad Fornazari
ORCID: https://orcid.org/0000-0002-4988-1561
Pontifícia Universidade Católica do Paraná, Brasil
E-mail: isabelleadad@ @mail.com
Evelise Machado de Souza
ORCID: https://orcid.org/0000-0002-7490-4868
Pontifícia Universidade Católica do Paraná, Brasil
E-mail: evelise.souza@ @ucpr.br
Rodrigo Nunes Rached
ORCID: https://orcid.org/0000-0003-4667-6762
Pontifícia Universidade Católica do Paraná, Brasil
E-mail: r.rached@ @ucpr.br

\begin{abstract}
This report describes the restoration of an anterior fractured tooth with a fiberglass CAD-CAM post-and-core followed by rapid orthodontic extrusion. The post space was prepared, the post-and-core was luted and a interim crown was luted to allow the tooth extrusion through the use of orthodontic buttons and elastic rubber bands. A lithium disilicate glass-ceramic crown was luted and the case was followed up after 6 and 12 months.
\end{abstract}

Keywords: Computer-aided design; Orthodontic extrusion; Ceramics.

\section{Resumo}

Este relato descreve a restauração de um dente anterior fraturado com um pino de fibra de vidro CAD-CAM seguido por extrusão ortodôntica rápida. $\mathrm{O}$ espaço do pino foi preparado, o pino e o núcleo foram cimentados e uma coroa provisória foi cimentada para permitir a extrusão do dente através do uso de botões ortodônticos e elásticos. Uma coroa de vitrocerâmica de dissilicato de lítio foi cimentada e o caso foi acompanhado após 6 e 12 meses.

Palavras-chave: Desenho assistido por computador; Extrusão ortodôntica; Cerâmica.

\section{Resumen}

Este relato de caso describe la restauración de un diente anterior fracturado con un poste y muñón CAD-CAM de fibra de vidrio seguido de una extrusión ortodóncica rápida. Se preparó el espacio del poste, y fueron cementados el poste, el muñón y una corona provisional para permitir la extrusión del diente mediante el uso de botones de ortodoncia y ligas elásticas. Se cementó una corona de cerámica de disilicato de litio y se realizó un seguimiento del caso a los 6 y 12 meses.

Palabras clave: Diseño asistido por computadora; Extrusión ortodóncica; Cerámica. 


\section{Introduction}

Intraradicular post-and-cores made of metal or fiberglass are widely used to provide retention to conventional crowns when restoring severely damaged teeth. The long-term success of this prosthetic rehabilitation depends on several characteristics such as color, biocompatibility, modulus of elasticity, and adaptation to the canal walls (Liu et al., 2010; Pang et al., 2019; Oliveira et al., 2021).

Prefabricated fiberglass posts have adequate mechanical properties and color; however, they may poorly fit into flared or irregular root canals. The preparation of the root canal with the matching drill of the selected fiberglass post can improve the adaptation, albeit it may result in undesirable wear of tooth structure (Chen et al., 2014). Although fiber post relining with restorative composite figures as an alternative, the lack of adhesion between fiberglass and composite and the occurrence of microbubbles/voids can result in failures (Sadek et al., 2007; Liu et al., 2010). Adhesive failures between composite cement and intraradicular dentin and crown displacement due to poor mechanical properties of the composite core have also been reported (Liu et al., 2010; Aleisa et al., 2016).

A customized one-piece post-and-core milled from a CAD-CAM (computer-aided design/computer-aided manufacturing) block aims to fill the entire post space with good adaptation (Liu et al., 2010; Moustapha et al., 2019). Among the different materials that can be milled, fiberglass CAD-CAM blocks are composed of an epoxy resin matrix and glass fibers. The modulus of elasticity of these blocks $(25 \mathrm{GPa})$ is very similar to that of dentin $(18.6 \mathrm{GPa})$ and is manufactured under controlled pressure and temperature, which makes them less susceptible to failure (Angelus, 2017).

Teeth that suffered significant loss of tissues (enamel, dentin, and pulp) that extend beyond the gingival margin and alveolar crest are very difficult to restore. Moreover, recontouring the alveolar crest of anterior teeth may be challenging due to esthetic demand (Brown \& Welbury, 2000; Braga \& Bocchieri, 2012). As an alternative, rapid orthodontic tooth extrusion substantially prevents the movement of both gingival margin and alveolar, which is considerably less in comparison with a mild and slow extrusion (Reitan et al., 1967; Cooke \& Scheer, 1980; Brown \& Welbury., 2000; Kim et al., 2004; Nascimento et al., 2021).

Although several restorative treatments with CAD-CAM materials have been demonstrated in the literature, there are no reports of customized intraradicular post-and-cores associated with the rapid orthodontic extrusion of anterior teeth (Linonati et al. 2020); Abreu et al., 2021). Therefore, this clinical case report aims to describe the restoration of a maxillary lateral incisor with a fiberglass CAD-CAM post-and-core followed by a rapid orthodontic extrusion and to demonstrate the potential of this restoration type to resist shear stress during extrusion.

\section{Methodology}

The present study is a descriptive qualitative clinical case study of a single patient (Pereira et al., 2018). This is based in an observation made during patient assessment. The patient signed the Informed Consent Form with information about the prognostic, risks and benefits and was aware of the dissemination of clinical images (without identification).

\section{Clinical Report}

A 48-year-old patient attended the dental clinic of the local university with a fractured maxillary right lateral incisor with an interim crown that has been made in a previous emergency care appointment. The buccal fracture line was located at the alveolar crest level. Since the gingival zenith of adjacent teeth (Figure 1) was at the same level, surgical crown lengthening would compromise esthetics; thus, rapid orthodontic extrusion was indicated to maintain both gingival and bone levels and 
replace the fracture line to a more favorable position. Adequate endodontic treatment and root length were observed on the radiograph (Figure 2).

Figure 1. Initial photograph of fractured right lateral incisor with an interim crown in place.

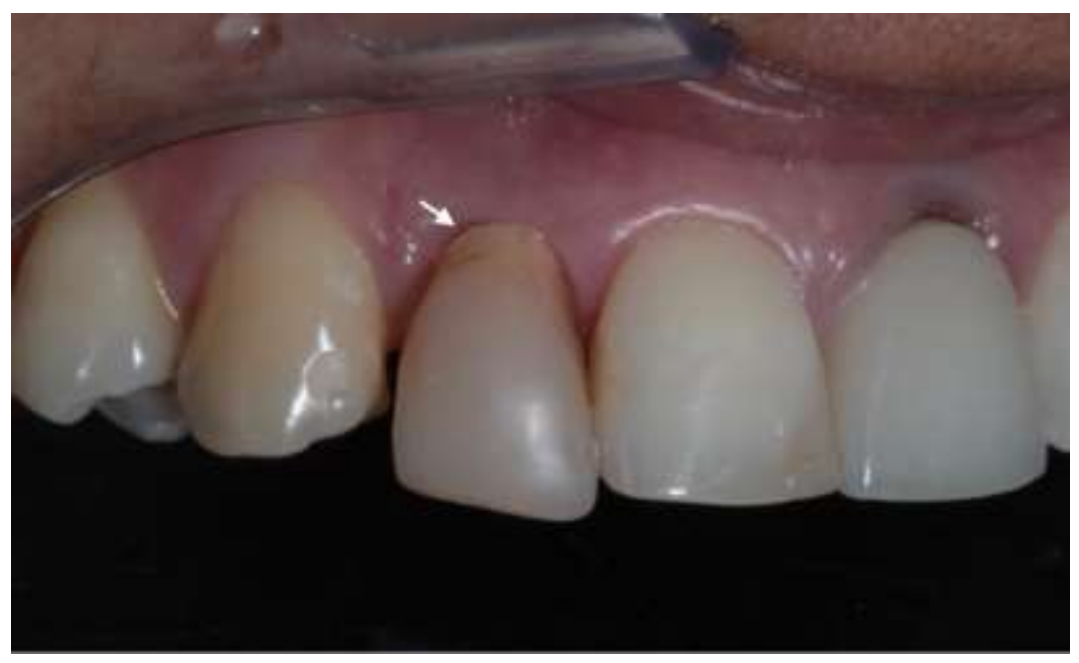

Source: Authors.

Figure 2. Initial radiograph of case showing adequate endodontic treatment.

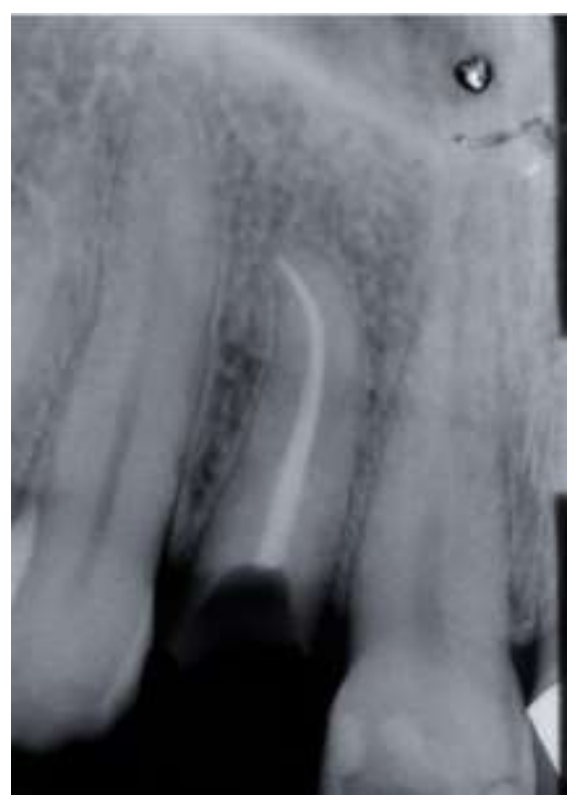

Source: Authors.

Considering that the tooth remnant had $16 \mathrm{~mm}$ in length, the post space was prepared at an 11-mm depth into the root canal with stainless steel reamer drills (Largo Peeso 1, 2, and 3; Microdont) at low speed. The post space with smooth wall surfaces and without retentions was cleaned and a water-based lubricant was applied. Next, a combination of polycarbonate post (PinJet; Angelus) and self-polymerized acrylic resin (Pattern Resin; GC) was used for intraradicular modeling and core build-up. The final core shape of the acrylic pattern was determined with a water-cooled $25-\mu \mathrm{m}$ grit diamond bur (2135FF; KG 
Sorensen) at low speed. Digital optical impression of the post-and-core pattern was taken with a laboratory scanner (Ceramill Map; AmannGirrbach) and the customized one-piece post-and-core was milled from a fiberglass CAD/CAM block (Fiber Cad Post \& Core; Angelus) (Figure 3).

Figure 3. Milled fiberglass post-and-core (white) and acrylic pattern.

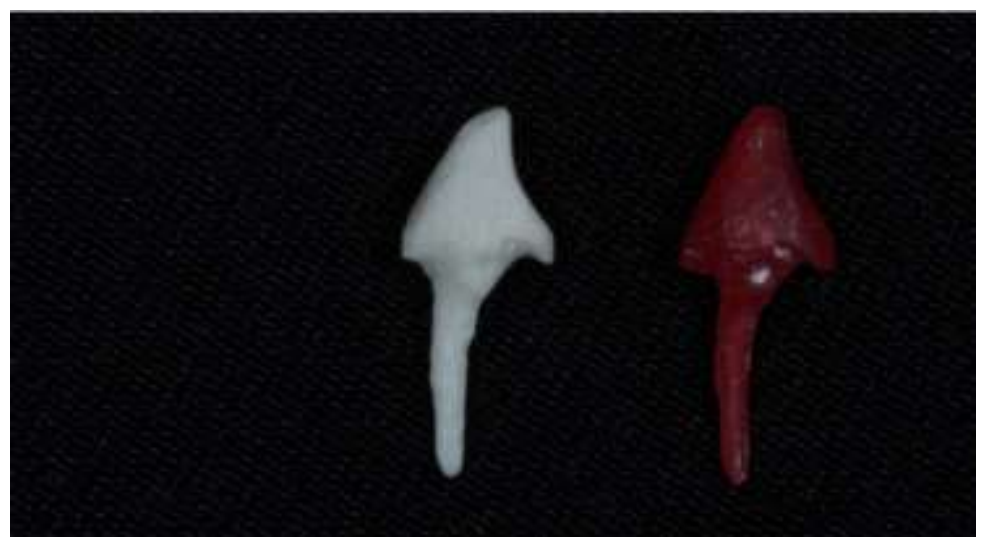

Source: Authors.

The adequate fit of the milled fiberglass post-and-core was clinically and radiographically confirmed (Figure 4). Then, the surface of the post-and-core was sandblasted with 50- $\mu \mathrm{m}$ aluminum oxide particles, ultrasonically cleaned, dried, and silanized. The post space was cleaned with alcohol and dried. The post-and-core was luted using a dual-polymerized selfadhesive resin cement (U200; 3M ESPE). Next, a interim acrylic resin crown (Alike; GC America) was luted with the same resin cement to withstand further shear stress during the orthodontic tooth extrusion.

Figure 4. Radiography of maxillary right lateral incisor with radiolucent fiberglass post-and-core adequate apical fit.

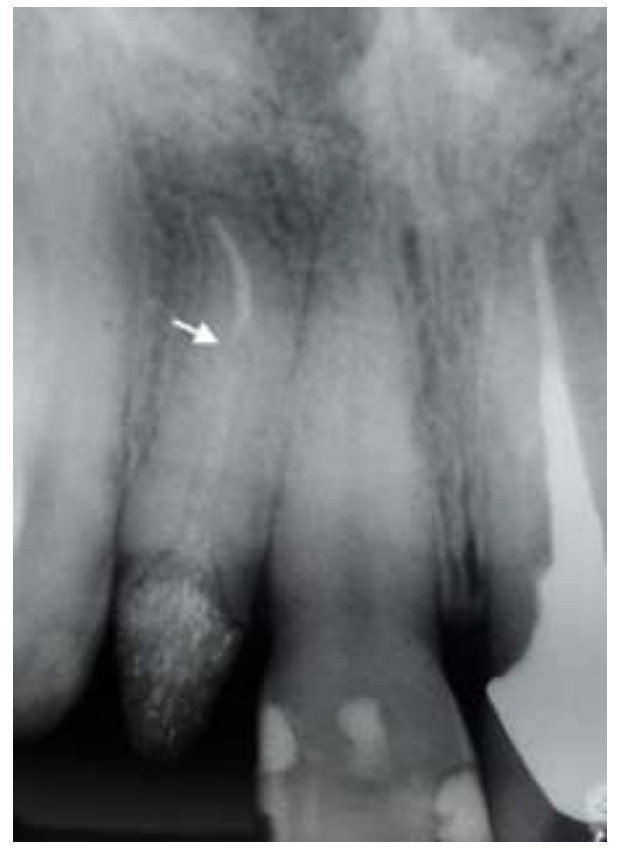

Source: Authors. 
Orthodontic buttons (Morelli) were bonded to the buccocervical region of the interim crown and the incisal region of both distal and mesial adjacent teeth. For the rapid extrusion of the lateral incisor, an intrasulcular incision was made above the button for the placement of an elastic band, which was supported by the adjacent teeth (Figure 5). The elastic chain was replaced every 10 days for 3 months until the cervical preparation finish line was located at 1 mm subgingivally (Figure 6). After this period, the teeth was kept stabilized in this position for 45 days to avoid any chances of the achieved position and the gingival margin was healthy enough to be restored with a ceramic crown.

Figure 5. Fixed orthodontic buttons and elastic band used for rapid extrusion of the maxillary right lateral incisor.

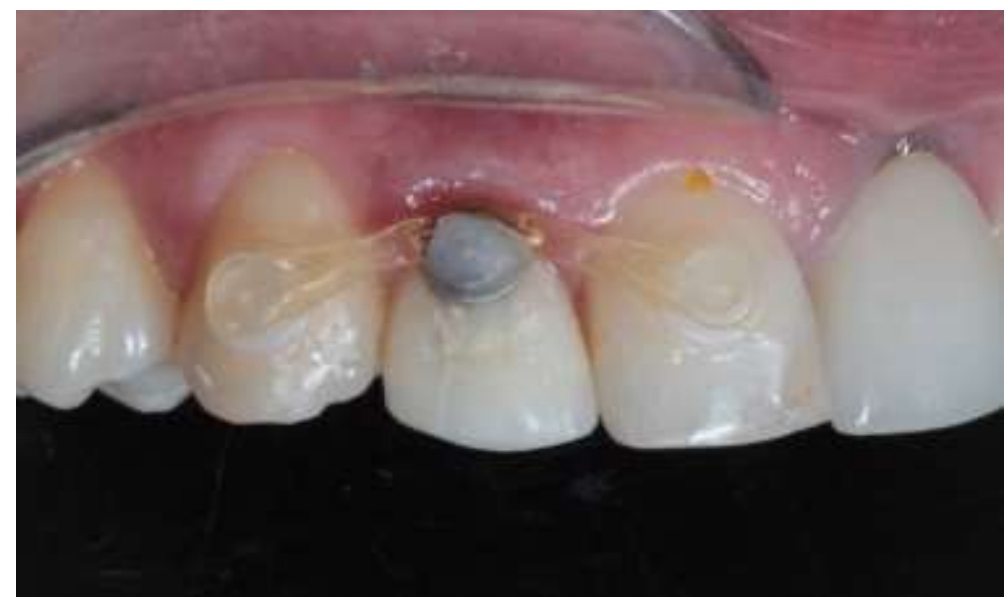

Source: Authors.

Figure 6. Final position of the teeth after the extrusion and the stabilization period.

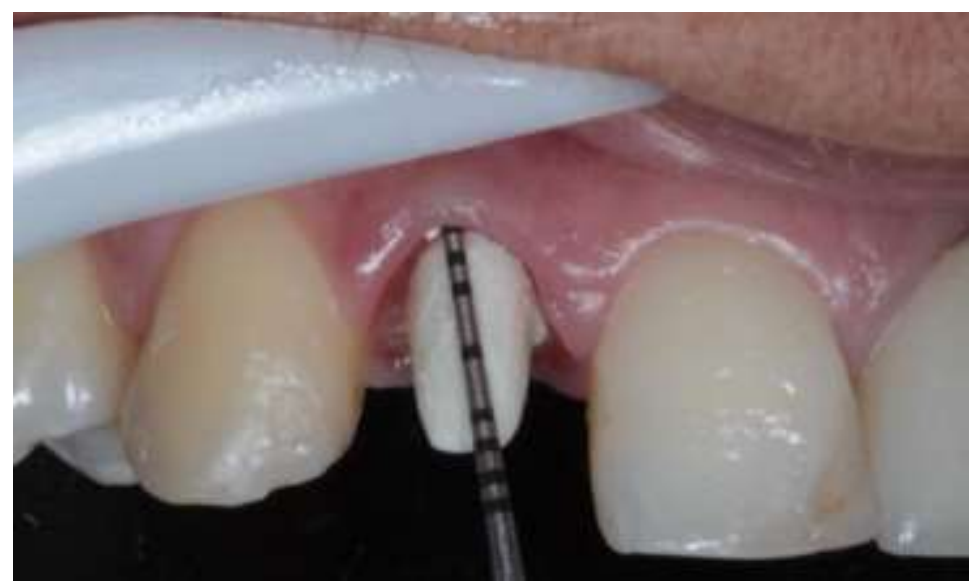

Source: Authors.

Then, a two-step impression of the crown preparation was taken with putty and light-body polyvinyl siloxane material (Virtual; Ivoclar Vivadent) to fabricate a lithium disilicate glass-ceramic crown (E.Max; Ivoclar Vivadent). After receiving the crown from the dental lab, its proper fit and marginal adaptation were confirmed and luting was performed with the same selfadhesive resin cement used for post-and-core luting. The clinical and radiographic follow-ups after 6 and 12 months (Figure 7) revealed adequate gingival profile, marginal and intraradicular adaptation of the post-and-core (Figure 8). 
Research, Society and Development, v. 10, n. 16, e337101623686, 2021

(CC BY 4.0) | ISSN 2525-3409 | DOI: http://dx.doi.org/10.33448/rsd-v10i16.23686

Figure 7. One year of radiograph follow-up showing apical and periodontal health.

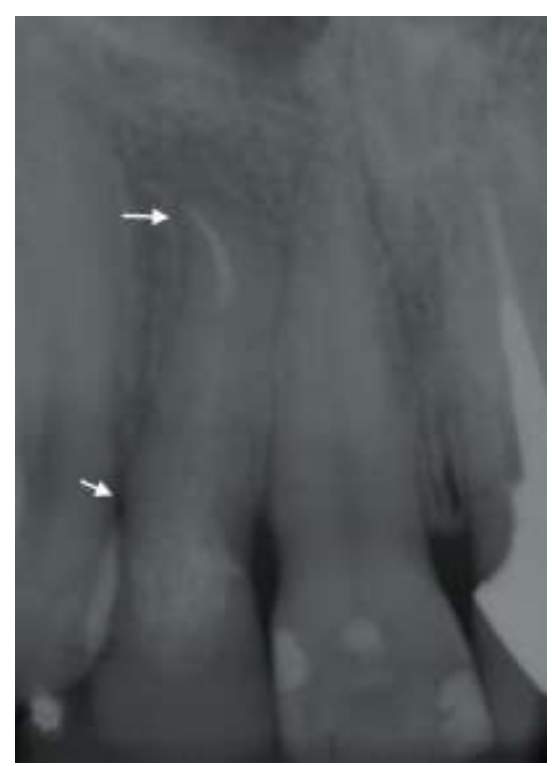

Source: Authors.

Figure 8. One year of clinical follow-up showing the lithium disilicate glass-ceramic crown.

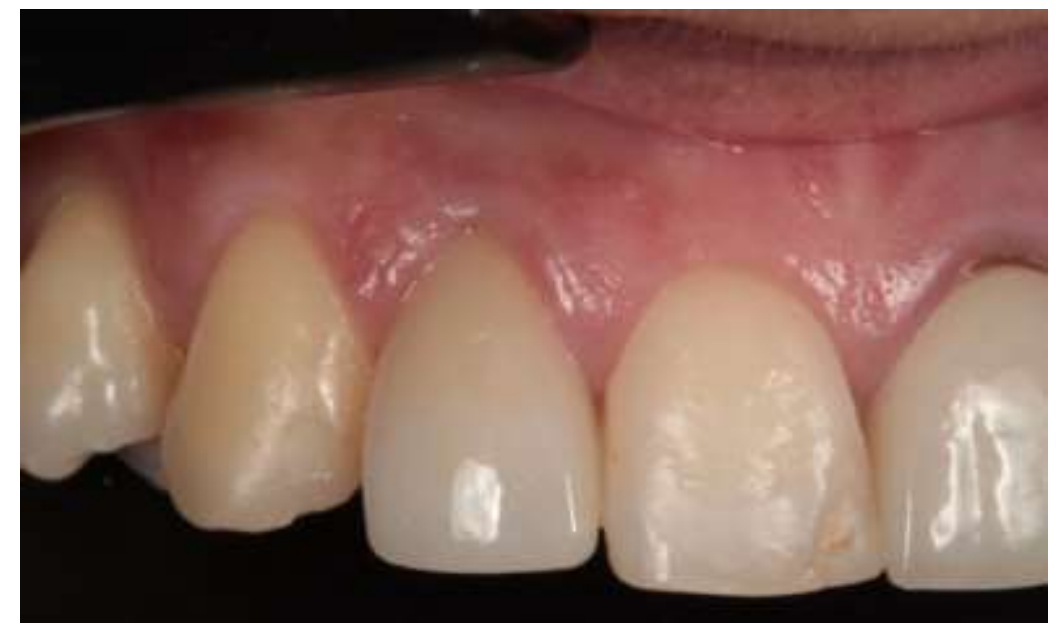

Source: Authors.

\section{Discussion}

This case report described the use of a fiberglass post-and-core customized by CAD-CAM technology for the restoration and rapid orthodontic extrusion of a maxillary lateral incisor with a subgingival crown fracture. Within the advantages, the modulus of elasticity of the fiberglass material is similar to that of dentin and the adhesion to the luting cement is optimize (Ramos et al. 2021). The improvement of the adhesion of the final restoration was achieved by the application of hydrofluoric acid in the internal surface of the crown (Faria et al., 2021). The dental lab costs involved and the need for an additional appointment figure as relative disadvantages (Amižić et al., 2018; Eid et al., 2019). 


\section{Final Considerations}

Prothestic rehabilitation of anterior teeth with subgingival fracture line rehabilitation can affect function, speech and esthetics. The method described combining orthodontic extrusion and fiberglass CAD-CAM post-and-core shows a conservative and ideal treatment. The authors reccomend the use of the technique to maintain natural tooth once it is not as expensive as dental implant and preserve the proprioception and dental adjacent tissues. We suggest that in vitro tests could be made to test the mechanical proprieties such as resistance and bonding strength.

\section{References}

Abreu, L. O., Romão, C. B. P., Alves, J. V., Pinheiro, K. N. B., Silva, G. M. T., Oliveira, M. A. C., Sousa, R. V., Coura, R. M., Oliveira, N. V. S. G., Oliveira Júnior, J. K. (2021). Oral rehabilitation in ceramic crown using digital flow: case report. Research, Society and Development, $10(14)$, (e)389101422212.

Aleisa, K., AL-Dwairi, Z. N., Alsubait, S. A., Morgano, S. M. (2016). Pull-out retentive strength of fiber posts cemented at different times in canals obturated with a eugenol-based sealer. J Prosthet Dent, 116:85-90.

Amižić, I. P., Miletić, I., Baraba, A., Fan, Y., Nathanson, D. (2018). In vitro retention of prefabricated and individually formed posts: A pilot study. J Prosthet Dent; $1-5$.

Braga, G., Bocchieri, A. (2012). A new flapless technique for crown lengthening after orthodontic extrusion. Int J Periodontics Restorative Dent, 32:81-90.

Brown, G. J., Welbury, R. R. (2000). Root extrusion, a practical solution in complicated crown-root incisor fractures. Br Dent J, 189:477-8.

Chen, Z., Li, Y., Deng, X. \& Wang, X. (2014). A novel computer-aided method to fabricate a custom one-piece glass fiber dowel-and-core based on digitized impression and crown preparation data. J Prosthodont, 23:276-83.

Cooke, M. S., Scheer, B. (1980) Extrusion of fractured teeth. The evolution of practical clinical techniques. Br Dent J, 149:50-3.

Eid, R. Y., Koken, S., Baba, N. Z., Ounsi, H., Ferrari, M., Salameh, Z. (2019) Effect of fabrication technique and thermal cycling on the bond strength of CAD/CAM milled custom fit anatomical post and core: an in vitro study. J Prosthodont, 28:898-905.

Faria, L. F., Cardoso, M. S., Lima, C. M., Melo, L. A., Leite, F. P. P. (2021). Influence of hydrofluoric acid etching time on the prosthetic adhesion of vitreous ceramics: a systematic review. Research, Society and Development, 10, (2), (e)18810212240.

Fiber Cad Post \& Core. (2017). Scientific documentation: Angelus.

Kim, C. S., Choi, S. H., Chai, J. K., Kim, C. K., Cho, K. S. (2004). Surgical extrusion technique for clinical crown lengthening: report of three cases. Int J Periodontics Restorative Dent, Oct;24:412-21.

Libonati, A., Di Taranto, V., Gallusi, G., Montemurro, E., Campanella, V. (2020). CAD/CAM customized glass fiber post and core with digital intraoral impression: A Case Report. Clin Cosmet Investig Dent, 12:17-24.

Liu P., Deng, X. L. \& Wang, X. Z. (2010). Use of a CAD/CAM-fabricated glass fiber post and core to restore fractured anterior teeth: A clinical report. J Prosthet Dent, 103(6):330-3.

Moustapha, G., AlShwaimi, E., Silwadi, M., Ounsi, H., Ferrari, M., Salameh, Z. (2019). Marginal and internal fit of CAD/CAM fiber post and cores. Int J Comput Dent. 22(1):45-53.

Nascimento, B. J., Silva, A. J. F., Prescinotti, R., Pedriali, M. B. B. P., Kasuya, A. V. B. Dental fracture with invasion of biological space: Multidisciplinary treatment. Research, Society and Development. 10(5), (e)42010515003, 2021.

Oliveira, L. K. B. F., Silva, S. R. C., Moura, V. S., Andrade, A.M.C., Torres, L.M.M., Silva, M.A.F., Santos, L. R. S., Silva, D. A., Gomes, J. De A., Gonçalves, E.G. (2021) Comparative analysis between fiberglass post and cast metal core: an integrative review. Research, Society and Development, 10(5), (e) 51610515236

Pang, J., Feng, C., Zhu, X., Liu, B., Deng, T., Gao, Y. (2019). Fracture behaviors of maxillary central incisors with flares root canals restored with CAD/CAM integrated glass fiber post-and-cores. Dent Mater J, 38:114-9.

Pereira, A.S., Shitsuka, D.M., Parreira, F.J., \& Shitsuka, R. (2018). Metodologia da pesquisa científica.

Ramos Júnior, S., Felizardo, K. R., Guiraldo, R. D., Berger, S. B., Ramos, N. B. P., De Assis, A. C. M., Lopes, M. (2021) B. CAD-CAM endodontic posts: literature review. Research, Society and Development, 10(1), (e)3210111314.

Reitan, K. (1967). Clinical and histologic observations on tooth movement during and after orthodontic treatment. Am J Orthod, 53:721-45.

Sadek, F. T., Monticelli, F., Goracci, C., Tay, F. R., Cardoso, P. E. C. \& Ferrari, M. (2007). Bond strength performance of different resin composites used as core materials around fiber posts. Dent Mater, 23:95-9. 